\title{
Brexit or Bremain? Future options for UK agricultural policy and the CAP
}

Article

Accepted Version

Swinbank, A. (2016) Brexit or Bremain? Future options for UK agricultural policy and the CAP. Eurochoices, 15 (2). pp. 5-10. ISSN 1478-0917 doi: https://doi.org/10.1111/1746-692X.12126 Available at https://centaur.reading.ac.uk/65623/

It is advisable to refer to the publisher's version if you intend to cite from the work. See Guidance on citing.

Published version at: http://onlinelibrary.wiley.com/doi/10.1111/1746-692X.12126/abstract

To link to this article DOI: http://dx.doi.org/10.1111/1746-692X.12126

Publisher: Wiley-Blackwell

All outputs in CentAUR are protected by Intellectual Property Rights law, including copyright law. Copyright and IPR is retained by the creators or other copyright holders. Terms and conditions for use of this material are defined in the End User Agreement.

\section{www.reading.ac.uk/centaur}

\section{CentAUR}

Central Archive at the University of Reading

Reading's research outputs online 


\title{
Brexit or Bremain? Future Options for UK Agricultural Policy and the CAP
}

\author{
Alan Swinbank
}

In November 2015 David Cameron (2015), Britain's Prime Minister, in a letter to Donald Tusk, President of the European Council, set out his demands for a 'new settlement' that he hoped to achieve 'for the United Kingdom in a reformed European Union'. On 19 February 2016, after protracted discussions, the EU's 28 Member States agreed a modified version of this 'new settlement' that will come into force if, and when, the UK decides to remain within the EU (European Council, 2016) in a referendum to be held on 23 June 2016. The question that will be posed, as set out in the European Union Referendum Act 2015, is 'Should the United Kingdom remain a member of the European Union or leave the European Union?' The electorate will, in the main, be as established for parliamentary elections: that is, it will include Irish and eligible Commonwealth citizens living in the UK, but exclude other EU nationals. Whatever the outcome - to remain (Bremain) or leave (Brexit) - the implications for agricultural policy are unclear.

For this Special Section of EuroChoices we asked Alan Matthews - whose writings on the blog CAPreform.eu, and elsewhere (e.g., Matthews, 2015) have already informed the discussion - to reflect further on the implications of Brexit from a non-UK perspective; and Wyn Grant - who chaired the preparation of a recent report for the Yorkshire Agricultural Society (YAS, 2016) - to discuss some of the challenges faced by UK agriculture. This Guest Editorial sets the scene, in particular by focussing on the constraints and opportunities Brexit would offer for future UK farm policy, whilst a Parlons Graphiques showing the current status of UK-EU agri-food trade completes the package.

\section{Bremain}

A vote to remain within the EU would bring new and unknown dynamics to the UK's relationship with its EU partners. A narrow majority would not necessarily dampen Eurosceptics' criticisms — neither those voiced by British Eurosceptics 
nor others elsewhere in Europe- or convince other Member States of the UK's whole-hearted embrace of the European venture. Disagreements about migration, the 'Brussels bureaucracy', budget contributions, etc., could still fuel distrust, despite Mr. Cameron's new settlement for a reformed European Union.

The other extreme, Giddens (2015) optimistically notes, would be a 'positive endorsement' following 'a full and informed public debate, a high turnout and a clear vote to stay in.' This, he observes 'is obviously the best-case Bremain scenario in which citizens are more fully informed than before and are persuaded of the positive benefits of EU membership.' Policy makers, NGOs and interest groups, and the wider public will need to think how they would wish to influence the future development of the EU's agri-food and rural policies, and plan their strategies: but that is not the theme of this Special Section of EuroChoices.

\section{Brexit}

A vote to leave would trigger a sequence of events, the eventual outcome of which is also highly uncertain. Some fear it could even result in the breakup of the UK. If, for example, the Scottish electorate voted decisively to stay within the EU, whereas a majority of UK citizens opted to leave, renewed calls for Scottish independence would probably arise.

Article 50 of the Treaty on European Union sets out the formal procedures, as explained by Grant in this issue. One might speculate on a spectrum of scenarios, ranging from an acrimonious separation, two years to the day after the UK's notification to quit, with no new UK-EU accord in place, through to a mutually advantageous agreement that could take much longer than two years to negotiate. Thus it is extremely difficult, if not impossible, to predict when Brexit might occur; but it might be that the British Government, mandated to leave the EU, would seek to do so in early 2019, before the end of the EU's current Financial Perspective. Would the Brits really want to elect members to the European Parliament in May 2019, or be bothered with the negotiations over a new College of Commissioners to take office on 1 November 2019? And 
Eurosceptic members of the British House of Commons might be rather keen to see the withdrawal completed before a new cadre of MPs is elected to the Commons in the General Election scheduled for May 2020.

\section{What would Brexit mean?}

With a referendum in sight and Brexit a credible outcome, the debate on EU membership has intensified and a number of reports have been triggered. Although some Brexit advocates have a clear vision of the future policies they would wish to see pursued, the National Farmers' Union's fairly neutral review of the consequences of Brexit with some justification commented: 'it is impossible to measure the impact of being outside of the EU since we do not know the relationship the UK would have, nor the conditions under which its farmers would be expected to operate if we did leave the $E U^{\prime}$ (NFU, 2015). Rather worryingly Elizabeth Truss, the UK's Secretary of State for Environment, Food and Rural Affairs, reportedly told journalists gathered at the 2016 Oxford Farming Conference that: 'The UK government is not working on an alternative plan for the country's farm sector in case the UK votes to leave the EU' (Agra Facts, No.01-16, 8 January 2016). Whilst Truss, who favours continued EU membership, has likened Brexit to a 'leap into the dark', George Eustice - her Eurosceptic junior in the Department for Environment, Food and Rural Affairs (Defra) - has reassured farmers that 'without a shadow of a doubt' the UK Parliament would ensure that farmers continued to receive the same level of support (Tasker, 2016).

The YAS (2016) report, rather like the earlier NFU (2015) document, does not attempt to advise farmers how to vote in the forthcoming referendum, nor to assess the economic impact of various Brexit scenarios. Instead it sets out in a fairly judicious fashion the farm policy issues that would have to be addressed on Brexit. Allan Buckwell's report (2016) for the Worshipful Company of Farmers engages rather more actively in an economic appraisal.

Although a number of authors and organisations have tried to assess the economic impact of Brexit on the economy as a whole, few have focussed specifically on agriculture. Boulanger \& Philippidis (2015) used computable 
general equilibrium modelling to assess the agricultural trade and budgetfunding dimensions of Brexit, finding that the UK's saving on its EU budget contributions tended to outweigh its losses that would arise from restrictions on agricultural trade. They suggest, in a comment pertinent to the arguments of the Bremain camp, 'the UK should realistically remain as an EU member, although continue to lobby for reductions in the CAP budget' (Boulanger \& Philippidis, 2015).

Brian Gardner's (2015) expensive and thus - to academics - rather inaccessible report prompted the newspaper headline: 'Brexit is a life or death matter for Britain's farmers'; and the comment: 'Land prices will crash. British agriculture will face a traumatic shock, and 90 per cent of the country's farmers will be ruined' (Evans-Pritchard, 2015). But, as Buckwell (2016) has pointed out: 'Frightening impacts can be suggested by showing data on the current dependence on direct payments of different UK farming systems and calculating the drop in farm business income if these payments were eliminated from one year to the next and nothing else changes.' Many analysts would expect some transition to a lower level of support, and economists would contest Gardner's static view of the world and suggest that farm businesses would instead adapt to changed circumstances.

\section{Constraints and opportunities}

If the UK decides to leave the EU, it might be thought that, freed of the constraints of the CAP and with the repatriation of the UK's contribution to the EU budget, policy-makers would have a blank sheet in designing new food, farm, and environmental policies, best suited to British circumstances. What sort of policy would the UK want? Some interest groups worried about 'food security', 'food miles', etc., might argue for a more heavily protected agricultural sector, aiming for self-sufficiency. Others (including the present author) might wish to see the UK adopt a freer trade policy for agri-food products and advocate a speedy conclusion of the Doha Round. Perhaps the most likely outcome, however, is that the farm lobby would seek to preserve the status quo, with UKfunded policies replacing existing CAP support provisions. Environmentalists 
would no doubt insist on no weakening of existing environmental regulations that are often based on EU provisions, and advocate some tweaking of present support measures to enhance their environmental credentials.

But policy-makers would not have the luxury of designing a policy from scratch. As a result of contracts entered into under the CAP's Rural Development Regulation, many land-based businesses would have on-going obligations and rights, which would extend into the future (YAS, 2016). In addition to these ongoing funding commitments, policy makers would face other constraints including: i) international obligations stemming from the UK's continued membership of the World Trade Organization (WTO) and, potentially, a trade agreement with the EU; ii) budget limits; and iii) political pressures exercised by the UK's former EU partners, the devolved administrations (i.e., for Scotland, Wales and Northern Ireland) where rather different perceptions of the need for farm support prevail, and farm, environment, and other groups wishing to influence the shape of future policy.

If not constrained by political concerns, it seems likely that the UK Treasury's first instinct would be to spend less on agricultural support, under any successor regime, than the EU and UK together currently spend in the UK. CAP Pillar I support - direct payments - would seem to be particularly vulnerable. But a substantial reduction in support to farmers might well be contested by the devolved administrations, and leading advocates of Brexit have said it would not happen.

Most commentators agree that the UK and the EU would have a mutual interest in negotiating a new WTO-compatible UK-EU trade regime, but how long those negotiations would last, what form the new relationship would take, and how agri-food trade would fit within the whole, is difficult to predict. The empty boxes in Table 1 suggest that there could be at least 11 possible scenarios! 
Table 1: Eleven possible scenarios for future UK-EU trade

\begin{tabular}{|l|l|l|l|}
\hline \multirow{2}{*}{$\begin{array}{c}\text { The UK's } \\
\text { relationship with } \\
\text { the EU }\end{array}$} & $\begin{array}{c}\text { Agriculture 'in' an } \\
\text { agreement }\end{array}$ & $\begin{array}{c}\text { Existing most- } \\
\text { favoured-nation } \\
\text { (mfn) tariffs }\end{array}$ & $\begin{array}{c}\text { Unilateral tariff } \\
\text { reduction by } \\
\text { the UK }\end{array}$ \\
\hline Customs Union & & & \\
\hline $\begin{array}{l}\text { European Economic } \\
\text { Area }\end{array}$ & & & \\
\hline $\begin{array}{l}\text { Simple Free Trade } \\
\text { Area (FTA) }\end{array}$ & & & \\
\hline No formal link & & & \\
\hline
\end{tabular}

Perhaps the simplest format, but the most unlikely outcome, would be to leave the EU but retain the existing customs union. The EU-Turkey customs union, however, largely excludes agriculture, and so if this precedent were to be followed, both the EU and the UK would apply their most-favoured-nation (mfn) tariffs on cross border agri-food trade.

If no arrangement could be negotiated (the bottom row of Table 1), then the EU and the UK would perforce trade with each other as WTO partners, applying their respective mfn tariffs against each other. Thus fresh lamb carcasses dispatched from the UK to France would face a tariff of 12.8 per cent plus $€ 1,713$ per tonne. Similarly, if the UK retained the mfn tariffs it currently applies on imports from outside the $E U$ it would now charge them on shipments from its former EU partners as well. Irish and Danish butter into the UK would pay $€ 1,896$ per tonne (for comparison the EU's support price for butter is $€ 2,463.9$ per tonne). As indicated by the final column of Table 1, under WTO rules the UK could unilaterally reduce its mfn tariffs, rather than continue to apply a tariff schedule inherited from its EU membership, but this is perhaps unlikely. Trade negotiators prefer to secure some quid pro quo from trading partners in exchange for tariff reductions. 
Between the two extremes of Table 1 are various versions of WTOcompatible Free Trade Area (FTA) agreements, either including or excluding agriculture. In its simplest form, an FTA would remove trade barriers on goods covered by the agreement and originating within the FTA. Rules of origin and border controls would be required to identify the shipments that can and those that cannot circulate freely. This essentially is the scenario that Boulanger and Philippidis (2015) model: a simple FTA that includes agriculture, whilst the UK continues to apply the EU's tariff regime on third country trade, with varying assumptions regarding the additional costs that would be incurred on UK-EU trade.

The European Economic Area (EEA), which includes Norway as well as the EU, goes further than this and extends many of the EU's regulatory internal market - provisions to the other EEA members. Norway has no formal say in determining these measures, and pays a membership fee to the EU for participating in the EEA, comparable in some respects to the UK's net contribution to the EU budget (House of Commons Library, 2013). Moreover, as with many of the EU's FTAs, trade in agri-food products is largely excluded from its provisions.

Would the UK's Eurosceptics be satisfied with an EEA-like outcome, particularly if the EU insisted on the inclusion of the internal market's four freedoms, 'concerning movement of goods, services, capital and labour'? Ireland's agri-food sector is particularly reliant on the UK market, and Irish beef producers for example would undoubtedly want beef to be included in any EEAlike agreement to gain easy access to the British market. But what if the UK then lowered its tariff on beef to all suppliers (as in the final column of Table1), allowing British consumers access to cheaper beef from Latin America for example, whilst continuing to export British bred and reared beef to the protected EU market?

WTO rules would not only constrain the form a future EU-UK trade agreement might take, but would also raise questions about how the EU's subsidy commitments established by the WTO Agreement on Agriculture might be shared by the UK and the remaining EU (if at all). There would also be 
questions about the extent to which the UK would have to assume part of the obligation to offer access to non-EU countries to its market, because of the tariff rate quotas (TRQs) in the current EU's Schedule of Commitments (YAS, 2016).

It might be assumed that the UK would simply drop out of the dozens of FTAs that the EU has with countries around the world, including those under negotiation such as the Transatlantic Trade and Investment Partnership (TTIP) with the USA, thereby forcing the UK to renegotiate dozens of trade deals. However, the situation may not be quite that simple. Most recent FTAs are socalled 'mixed' agreements that have been ratified by both the EU and each of the Member States, and just how they would be unravelled and repackaged is unclear. But in its May 2015 Election Manifesto, the Eurosceptic UK Independence Party (UKIP, 2015) said: 'Once the UK leaves the EU, we, as a country, regain our ability to take back our vacant seat at the WTO and represent ourselves, negotiating our own trade agreements and advancing our own national trade interests. A first step would be to broker a bespoke UK-EU trade agreement, which we believe is desirable. This is what we will seek and without doubt achieve, possibly within a very short period of time.'

\section{Wider ramifications}

As hinted above, and explored more fully by Alan Matthews elsewhere in this issue, Brexit has implications not just for the UK but also for the remaining EU states, and for world trade. Whilst the UK's withdrawal from the EU could generate a 'Brexit dividend' for the UK Treasury, which Eurosceptics argue could be used to fund a generous level of support for farm and environmental policies in the UK, there would be a corresponding loss of funds to the EU budget. Would this trigger a lower level of CAP support in the EU's next (i.e., post-2020) Multiannual Financial Framework (MFF); and if not how would the EU's budget shortfall be resolved?

The UK is often portrayed as a leading advocate of further CAP reform, although in practice one might question how committed it has been in pursuit of its stated objectives (Swinbank, 2015). Would an EU of 27 member states be less 
likely to further liberalise its agri-food policies, or even back-track on past reforms, if the UK no longer had a seat in the Council chamber or members in the European Parliament? In the WTO, would the UK be an ally of the EU on agricultural policies, or would it advocate more sweeping changes to the WTO Agreement on Agriculture than the EU would wish to contemplate? Might it even use its insider knowledge to challenge aspects of the CAP?

Whatever the outcome of the referendum, whether the UK leaves or remains within the EU, European governments will continue to grapple with the enduring challenges of agricultural, food, and rural land use policies. They will be expected to protect the interests of consumers and taxpayers, whilst meeting the legitimate expectations of farmers and landowners, and to reconcile commercial conflicts in a food chain via which most food is bought from large multiple retailers. They need to assure their citizens that they will have continuing access to a safe, nutritious, and affordable supply of food, whilst combatting obesity and diet-related disease. The electorate will expect land to be farmed sustainably, enhancing its environmental services, and responsive to the challenges of global warming and world population growth. And other nations will expect these policies to be delivered in a way that respects their legitimate interests and international obligations.

\section{Further Reading}

Boulanger, Pierre \& George Philippidis (2015), The End of a Romance? A Note on the Quantitative Impacts of a 'Brexit' from the EU, Journal of Agricultural Economics, 66(3): 832-42.

Buckwell, Allan (2016), Agricultural implications of Brexit (Worshipful Company of Farmers: London).

Cameron, David (2015), A New Settlement for the United Kingdom in a Reformed European Union, Letter to His Excellency Mr Donald Tusk, 10 Downing Street, 10 November: https://www.gov.uk/government/uploads/system/uploads/attachment data/fi le/475679/Donald Tusk letter.pdf, accessed 26 January 2016.

EFTA (no date), The Basic Features of the EEA Agreement at http://www.efta.int/eea/eea-agreement/eea-basic-features, accessed 26 January 2016. 
European Council (2016), European Council meeting (18 and 19 February 2016) Conclusions, EUCO 1/16, 19 February (European Council: Brussels):

http://www.consilium.europa.eu/en/press/press-releases/2016/02/19-eucoconclusions/, accessed 20 February 2016.

Evans-Pritchard, Ambrose (2015), Brexit is a life or death matter for Britain's farmers, The Telegraph, 1 November 2015:

http://www.telegraph.co.uk/finance/economics/11967049/Brexit-is-a-life-ordeath-matter-for-Britains-farmers.html, accessed 25 January 2016.

Gardner, Brian (2015), Preparing for Brexit: What UK withdrawal from the EU would mean for the agri-food industry (Informa Agra: London). A Webinar in which Gardner presents a summary of his report is available at https://www.agra-net.com/agra/agra-europe/policy-andlegislation/cap/webinar-how-will-a-brexit-impact-agriculture-in-the-uk-and-eu496878.htm, accessed 25 January 2016.

Giddens, Anthony (2015), Britain teeters closer to the brink of Brexit, Europe's World: http://europesworld.org/2015/02/24/britain-teeters-closer-brinkbrexit/\#.VqXl8TZGzwx, accessed 25 January 2016.

House of Commons Library (2013), Leaving the EU, Research Paper 13/42 (House of Commons: London).

Matthews, Alan (2015), Implications of British exit from the EU for the Irish agrifood sector, TEP Working Paper No. 0215 (Department of Economics, Trinity College: Dublin).

National Farmers Union (2015), EU Referendum: UK Farming's Relationship with the EU (NFU: Stoneleigh).

Swinbank, Alan (2014), 'If the British left: Agricultural policy outside the CAP?', EuroChoices, 13(2): 36-9.

Swinbank, Alan (2015), CAP Reform, 2005-14, and the Muted Role of the DisUnited Kingdom, in Johan Swinnen (ed.) The Political Economy of the 2014-2020 Common Agricultural Policy: An Imperfect Storm (Rowman \& Littlefield International: London).

Tasker, Johann (2016), Minister reveals EU exit plan for British agriculture, Farmers Weekly, 25 February: http://www.fwi.co.uk/news/minister-reveals-euexit-plan-for-british-agriculture.htm, accessed 5 March 2015.

UKIP (2015), Believe in Britain. UKIP Manifesto 2015 (UK Independence Party: Newton Abbot).

Yorkshire Agricultural Society (Farmer Scientist Network) (2016), The Implications of 'BREXIT' for UK Agriculture. A report for the Yorkshire Agricultural Society (YAS: Harrogate).

Alan Swinbank, Emeritus Professor of Agricultural Economics, University of Reading, UK. Email: a.swinbank@reading.ac.uk 


\section{Summary}

The outcome of the UK's referendum on continued EU membership is at the time of writing uncertain, and the consequences of a vote to remain ('Bremain') or leave ('Brexit') difficult to predict. Polarised views have been voiced about the impact of Brexit on UK agriculture, and on the nature, and level of funding, of future policy. Policy makers would not have the luxury of devising a new policy from scratch. WTO rules and commitments, the nature of any future accord with the EU, budget constraints, the rather different perspectives of the UK's devolved administrations in Scotland, Wales and Northern Ireland, and the expectations of farmers, landowners, and the environmental lobby, will all impact the policymaking process. The WTO dimension, and the UK's future relationship with the $\mathrm{EU}$, are particularly difficult to predict, and - some commentators believe may take years to resolve. Brexit's impact on the future CAP is also unclear. A vote to remain within the EU would not necessarily assuage the Eurosceptics' criticisms of the EU, or the UK's perception of the CAP. Whatever the outcome, future agricultural, food, and rural land use policies will remain key preoccupations of European governments.

\section{Pullquote}

"If the UK decides to leave the EU ... policy-makers would not have the luxury of designing a policy from scratch" 